\title{
FAKTOR-FAKTOR YANG BERHUBUNGAN DENGAN KEJADIAN MIOMA UTERI DI RUMAH SAKIT KOTA BENGKULU TAHUN 2012
}

\author{
Erlindawati, Sri Sumiati \\ Poltekkes Bengkulu, Jurusan Kebidanan, Jl. Indragiri No.3 Bengkulu \\ Poltekkes Bengkulu, Jurusan Kebidanan, Jl. Indragiri No.3 Bengkulu
}

\begin{abstract}
The uterine myoma is the major maligna problem in the woman reproduction that causing the clinical syndrome especially bleeding, excessive menstruation, infertility, the repeatedly abortus, and pain due to the mass pressure. The problem of the research is the increasing numbers of the myoma case. The aim of the research is to reveal the relation between the uterine myoma and the age of mother, parity, menarche age, obesity, and the hormonal contraception in the hospital of Bengkulu. This research is a kind of analytical survey. The designed used in this research is case. The population is all mothers with the gynecological health problem, which is 1045 in number. The sample of the research is 106 mothers. The group case is 53 respondent with 53 respondent of group control, taken total sampling. The result of the research shows that there is relation between the mother age and the uterine myoma, the value: $\rho=0,000$. The result also shows that there is no relation between the parity and uterine myoma, the value $\rho=$ 0,643 . There is norelation between the obesity and the uterine myoma, the value $\rho=0,104$. Moreover, it is also known that there is relation between hormonal contraception and the uterine myoma, the value $\rho=0,05$. It is suggested to the medical officer to always giving the proper counseling about the risk of uterine myoma, so the acceptor can choose the most feaseable and the most suitable contraception for her. It is also suggested to the women in the fertilize age to be aware of the risk of uterine myoma. It is can be by doing the advanced medical check up to the abnormal menstruation cycle syndrome.
\end{abstract}

\begin{abstract}
Abstrak : Mioma uteri adalah masalah maligna besar dalam reproduksi wanita yang menyebabkan sindrom klinis terutama perdarahan, menstruasi yang berlebihan, infertilitas, abortus yang berulang kali dan nyeri karena tekanan massa. Masalah pada penelitian ini adalah meningkatnya jumlah kasus miom. Tujuan dari penelitian ini adalah untuk mengetahui hubungan antara mioma uteri dengan umur ibu, paritas, usia menarche, obesitas dan kontrasepsi hormonal di Rumah Sakit Bengkulu. Jenis penelitian ini adalah jenis survey analitik, rancangan yang digunakan adalah rancangan kasus. Populasi adalah semua ibu dengan masalah kesehatan ginekologi yaitu berjumlah 1045 dengan jumlah sampel 106 yaitu 53 kelompok kasus dan 53 orang kelompok control . Hasil penelitian menunjukkan bahwa ada hubungan antara usia ibu dengan mioma uteri $(\rho=0,00)$. Tidak ada hubungan antara paritas dengan mioma uteri $(\rho=0,643)$. Ada korelasi antara obesitas dan mioma uteri $(\rho=0,104)$. Selain itu juga diketahui bahwa ada hubungan antara kontrasepsi hormonal dengan mioma uteri $(\rho=0,05)$. Disarankan kepada petugas kesehatan untuk selalu memberikan konseling yang tepat tentang resiko miom uterus, sehingga akseptor dapat memilih kontrasepsi yang paling cocok. Hal ini juga disarankan untuk para wanita diusia subur untuk menyadari risiko miom rahim dengan melakukan check up lanjutan pada siklus menstruasi yang tidak normal.
\end{abstract}

Kata Kunci : umur, paritas, usia menarche, obesitas, kontrasepsi hormonal, mioma uteri

Kesehatan merupakan salah satu faktor yang sangat menentukan kualitas Salah satu masalah kesehatan reproduksi wanita adalah mioma uteri. Mioma uteri adalah neoplasma jinak yang bersal dari otot uterus dan jaringan ikat, yang dalam kepustakaan ginekologi dikenal dengan istilah fibrimyoma uteri atau leiomyoma atau fibroid (Mansjoer, 2007).
Sampai saat ini penyebab mioma uteri belum diketahui secara pasti, namun menurut Parker (2007) faktor predisposisi dari mioma uteri adalah usia penderita, usia menarche, olahraga, diet, riwayat keluarga, hormonal/kontrsepsi hormonal, ras, paritas dan obesitas.

Estrogen berperan sebagai penyebab terjadinya mioma uteri dan berpengaruh 
terhadap pertumbuhannya. Mioma uteri terdiri dari reseptor estrogen dengan konsistensi lebih tinggi dari miometrium sekitarnya namun konsistensinya lebih rendah dari endometrium. Di indonesia penggunaan hormon sebagai alat kontrsepsi sudah populer dalam masyarakat. Pemakai kontrasepsi hormonal terbanyak adalah jenis suntikan dan pil. Kontrsepsi oral (pil) yang paling banyak digunakan yaitu kombinasi estorgen dan progesteron (Harianto, 2010). Hasil penelitian yang dilakukan Jian et-al (2010), diperoleh hasil bahwa wanita yang menggunakan kontrasepsi oral memiliki resiko menderita mioma 1,6 kali di banding wanita yang tidak menggunakan kontrasepsi oral.

Berdasarkan laporan kejadian mioma uteri di RSUD dr, M. Yunus Bengkulu tahun 2009 kejadian mioma uteri berjumlah 64 orang $(2,4 \%)$ dari 2663 kasus ginekologi dan tahun 2010 tercatat 96 orang $(2,6 \%)$ penderita mioma uteri dari 3587 kasus ginekologi dan tahun 2011 tercatat 167 (4, $6 \%$ ) orang penderita mioma uteri dari 3609 kasus ginekologi. Angka ini menunjukkan meningkatnya jumlah penderita mioma uteri setiap tahunnya. Data yang diperoleh di RS Raflesia Bengkulu dari survei pendahuluan terdapat 42 penderita pada tahun 2009-2011 . Rincian tiap tahun yaitu pada tahun 2009 dengan jumlah 10 (12\%) penderita dari 83 kasus ginekologi, tahun 2010 dengan jumlah $15(6,5 \%)$ penderita dari 230 kasus ginekologi, tahun 2011 dengan jumlah 17 (8,5\%) penderita dari 199 kasus ginekologi. Tujuan penelitian ini adalah mengetahui faktor-faktor apa saja yang berhubungan dengan kejadian mioma uteri.

\section{BAHAN DAN CARA KERJA}

Jenis Penelitian ini adalah (survey) analitik dengan pendekatan case control yaitu melakukan pengukuran variabel efek (kejadian mioma uteri) diidentifikasi saat ini kemudian variabel resiko (usia, paritas, usia menarche, obesitas dan kb hormonal) di identifikasi adanya atau terjadinya pada waktu yang lalu.
Populasi dalam penelitian ini adalah seluruh Ibu yang mengalami gangguan ginekologi Di Rumah Sakit Kota Bengkulu 2012. Sampel dalam penelitian ini adalah ibu yang menderita mioma uteri berjumlah 53 orang sebagai kelompok kasus, yang diambil secara Total sampling. Sedang kelompok kontrol adalah ibu yang tidak menderita mioma uteri sebanyak 53 kasus dan diambil secara systematic random sampling dengan perbandingan 1:1.

Penelitian ini menggunakan data sekunder yang diperoleh dari data register dari bulan Januari sampai dengan Juli 2012. Analisis yang dilakukan pada penelitian ini adalah analisis univariat dan analisis bivariat dengan menggunakan uji chi squ-are $\left(\mathrm{x}^{2}\right)$ pada $\alpha 5 \%$. Sedangkan untuk me-lihat keeratan hubungan kedua variabel, menggunakan nilai OR (Odd rasio).

\section{HASIL}

\section{Analisis Univariat}

Analisis univariat untuk menggambarkan distribusi frekuensi masing-masing variabel, dari tabel di bawah ini dapat di lihat bahwa dari 53 orang responden yang mengalami mioma uteri (kasus) menunjukkan bahwa hampir seluruh $(75,5 \%)$ responden berusia $>35$ tahun, sebagian kecil responden $(24,5 \%)$ adalah nullipara, hampir sebagian responden $(30,2 \%)$ dengan usia menarche $<10$ tahun, sebagian kecil $(9,4 \%)$ responden mengalami obesitas dan hampir seluruh responden $(77,4 \%)$ menggunakan KB hormonal. Sedangkan dari 53 orang responden yang tidak mengalami mioma $\mathrm{u}-$ teri (kontrol) menunjukkan hampir sebagian responden $(41,5 \%)$ berusia $\geq 35$ tahun, sebagian kecil responden $(20,8 \%)$ adalah nulipara, hampir sebagian responden $(34 \%)$ dengan usia menarche $<10$ tahun, sebagian kecil responden $(20,8 \%)$ mengalami obesitas dan sebagian besar responden $(50,9 \%)$ menggunakan kb hormonal. 
Tabel 1. Distribusi Frekuensi Usia,Paritas, Menarche, Obesitas, KB-hormonal responden di Rumah sakit kota Bengkulu Tahun 2012

\begin{tabular}{|c|c|c|c|c|}
\hline \multirow[b]{2}{*}{ Variabel } & \multicolumn{2}{|c|}{ Kasus } & \multicolumn{2}{|l|}{ Kontrol } \\
\hline & Jumlah (n) & Persentase (\%) & Jumlah (n) & Persentase (\%) \\
\hline \multicolumn{5}{|l|}{ Usia Ibu } \\
\hline$\geq 35$ tahun & 40 & 75,5 & 22 & 41,5 \\
\hline$<35$ tahun & 13 & 24,5 & 31 & 58.5 \\
\hline \multicolumn{5}{|l|}{ Paritas } \\
\hline Nullipara & 13 & 24,5 & 11 & 20,8 \\
\hline Multipara & 40 & 75,5 & 42 & 79,2 \\
\hline \multicolumn{5}{|l|}{ Usia menarche } \\
\hline$<10$ tahun & 16 & 30,2 & 18 & 34 \\
\hline$\geq 10$ tahun & 37 & 69,8 & 35 & 66 \\
\hline \multicolumn{5}{|l|}{ Obesitas } \\
\hline $\mathrm{IMT} \geq 25$ & 5 & 9,4 & 11 & 20,8 \\
\hline $\mathrm{IMT}<25$ & 48 & 90.6 & 42 & 79,2 \\
\hline \multicolumn{5}{|l|}{ Kb hormonal } \\
\hline Ya & 41 & 77,4 & 27 & 50,9 \\
\hline Tidak & 12 & 22,6 & 26 & 49,1 \\
\hline Jumlah & 53 & 100 & 53 & 100 \\
\hline
\end{tabular}

\section{Analisa Bivariat}

Analisa Bivariat untuk melihat hubungan antara usia, paritas, usia menarche, obesitas, $\mathrm{Kb}$ hormonal dengan kejadian mioma uteri di rumah sakit Kota Bengkulu tahun 2012.

Dari tabel 2 di bawah ini menunjukkan bahwa dari 53 responden yang mengalami mioma uteri, hampir seluruh $(75,5 \%)$ responden berusia $\geq 35$ tahun, sebagian kecil $(24,5 \%)$ responden berusia $<35$ tahun. Sedangkan dari 53 responden yang tidak mengalami mioma uteri, hampir sebagian responden $(41,5 \%)$ berusia $\geq 35$ tahun dan sebagian besar $(58,5)$ responden berusia $<35$ tahun. Hasil penelitian yang dilakukan responden yang berusia $<35$ tahun mengalami mioma uteri dan responden yang berusia $\geq$ 35 tahun tapi tidak mengalami mioma $\mathrm{u}$ teri, ini dapat dipengaruhi oleh faktor lain seperti paritas dan usia menarche.

Hasil analisis chi-square $\left(X^{2}\right)$ didapat nilai $p=0,000 \alpha=0,05$, artinya ada hubungan antara usia dengan kejadian mioma uteri di Rumah Sakit Kota Bengkulu tahun 2012. Selain itu diperoleh nilai OR 4,336 artinya ibu yang berusia $\geq 35$ tahun mempunyai resiko/berpeluang mengalami mioma uteri 4,336 kali dibanding ibu dengan usia $<35$ tahun.

Tabel 2. Hubungan Usia Ibu dengan Kejadian Mioma Uteri di Rumah Sakit Kota Bengkulu Tahun 2012

\begin{tabular}{|c|c|c|c|c|c|c|}
\hline \multirow[t]{2}{*}{ Usia ibu } & \multicolumn{2}{|c|}{$\begin{array}{l}\text { Mioma Uteri } \\
\quad(n=53)\end{array}$} & \multicolumn{2}{|c|}{$\begin{array}{c}\text { Tidak Mioma Uteri } \\
(n=53)\end{array}$} & \multirow[t]{2}{*}{ Nilai $p$} & \multirow{2}{*}{$\begin{array}{c}\text { OR } \\
(95 \% C I)\end{array}$} \\
\hline & $\mathrm{n}$ & $\%$ & $\mathrm{n}$ & $\%$ & & \\
\hline$\geq 35$ tahun & 40 & 75,5 & 22 & 41,5 & \multirow{2}{*}{0,000} & \multirow{2}{*}{4,336} \\
\hline$<35$ tahun & 13 & 24,5 & 31 & 58.5 & & \\
\hline
\end{tabular}

Dari tabel 3 menunjukan bahwa dari 53 yang menderita mioma uteri, sebagian kecilnya $(24,5 \%)$ adalah nulipara. Dan hampir seluruh $(75,5 \%)$ responden adalah multipara. Sedangkan dari 53 responden yang tidak mengalami mioma uteri, sebagian kecil $(20,8 \%)$ adalah nulipara dan hampir seluruh $(79,2 \%)$ responden adalah multi para. Dari penelitian yang dilakukan ditemukan responden yang multipara mengalami mioma uteri dan responden yang nullipara tetapi tidak mengalami mioma uteri.

Hasil analisis chi-square $\left(X^{2}\right)$ didapat nilai $p=0,643>\alpha=0,05$, artinya tidak ada hubungan antara paritas dengan kejadian mioma uteri di kota Bengkulu tahun 2012. Selain itu diperoleh OR 1,241 artinya responden yang nullipara memiliki risiko/peluang mengalami mioma uteri 1,241 kali dibanding responden yang multipara. 
Tabel 3. Hubungan Paritas dengan Kejadian Mioma Uteri di Rumah Sakit Kota Bengkulu Tahun 2012

\begin{tabular}{|c|c|c|c|c|c|c|}
\hline \multirow[t]{2}{*}{ Paritas } & \multicolumn{2}{|c|}{$\begin{array}{l}\text { Mioma Uteri } \\
(n=53)\end{array}$} & \multicolumn{2}{|c|}{$\begin{array}{c}\text { Tidak Mioma Uteri } \\
(n=53)\end{array}$} & \multirow[t]{2}{*}{ Nilai $p$} & \multirow{2}{*}{$\begin{array}{c}\text { OR } \\
(95 \% C I)\end{array}$} \\
\hline & $\mathrm{n}$ & $\%$ & $\mathrm{n}$ & $\%$ & & \\
\hline Nullipara & 13 & 24,5 & 11 & 20,8 & 0,643 & 1.241 \\
\hline Multipara & 40 & 75,5 & 42 & 79,2 & & \\
\hline
\end{tabular}

Dari tabel 4 menunjukkan bahwa dari 53 orang responden yang mengalami mioma uteri, hampir sebagian dengan usia menarche $<10$ tahun dan sebagian besar $(69,8 \%)$ responden dengan usia menarche $\geq 10$ tahun. Sedangkan dari 53 responden yang tidak mengalami mioma uteri, hampir sebagian responden (34\%) dengan usia menarche $<10$ tahun dan sebagian besar responden $(66 \%)$ dengan usia menarche $\geq 10$ tahun. Hasil penelitian yang dilakukan ditemukan responden dengan usia menarche $\geq 10$ tahun mengalami mioma uteri dan res- ponden dengan usia menarche $<10$ tahun tetapi tidak mengalami mioma uteri.

Hasil analisis chi-square $\left(X^{2}\right)$ didapat nilai $p=0,677>\alpha=0,05$, artinya tidak ada hubungan antara usia menarche dengan kejadian mioma uteri di umah sakit Kota Bengkulu tahun 2012. Selain itu diperoleh hasil OR 0,841 artinya responden dengan usia menarche $<10$ tahun mempunyai risiko mengalami mioma uteri 0,841 kali dibanding responden dengan usia menarche $\geq 10$ tahun.

Tabel 4. Hubungan Usia Menarche dengan Kejadian Mioma Uteri di Rumah Sakit Kota Bengkulu Tahun 2012

\begin{tabular}{|c|c|c|c|c|c|c|}
\hline \multirow[t]{2}{*}{ Usia menarche } & \multicolumn{2}{|c|}{$\begin{array}{c}\begin{array}{c}\text { Mioma Uteri } \\
(n=53)\end{array} \\
\end{array}$} & \multicolumn{2}{|c|}{$\begin{array}{c}\text { Tidak Mioma Uteri } \\
(n=53)\end{array}$} & \multirow[t]{2}{*}{ Nilai $p$} & \multirow{2}{*}{$\begin{array}{c}\text { OR } \\
(95 \% C I)\end{array}$} \\
\hline & $\mathrm{n}$ & $\%$ & $\mathrm{n}$ & $\%$ & & \\
\hline$<10$ tahun & 16 & 30,2 & 18 & 34 & 0,677 & 0.841 \\
\hline$\geq 10$ tahun & 37 & 69,8 & 35 & 66 & & \\
\hline
\end{tabular}

Dari Tabel 5. diatas menunjukkan bahwa dari 53 orang responden yang menderita mioma uteri, sebagian kecil $(9,4 \%)$ responden dengan nilai IMT $\geq 25$ dan hampir seluruh $(90,6 \%)$ responden dengan nilai IMT < 25. Dan dari 53 responden yang tidak mengalami mioma uteri sebagian kecil $(20,8 \%)$ responden dengan nilai IMT $\geq$ 25 , dan sebagian besar $(79,2 \%)$ responden dengan nilai IMT <25. Dari hasil penelitian yang dilakukan ditemukan responden dengan nilai IMT <25 mengalami mioma ute- ri dan ditemukan responden dengan nilai IMT $\geq 25$ tidak mengalami mioma uteri.

Hasil analisis chi-square $\left(X^{2}\right)$ didapat nilai $p=0,104>\alpha=0,05$, artinya tidak ada hubungan antara Obesitas dengan kejadian mioma uteri dirumah sakit kota Bengkulu tahun 2012. Selain itu diperoleh nilai OR 0,398 artinya responden dengan IMT $\geq 25$ mempunyai risiko/berpeluang mengalami mioma uteri 0,398 kali dibanding responden dengan nilai IMT $<25$.

Tabel 5. Hubungan Obesitas dengan Kejadian Mioma Uteri di Rumah Sakit Kota Bengkulu Tahun 2012

\begin{tabular}{|c|c|c|c|c|c|c|}
\hline \multirow{2}{*}{ Obesitas } & \multicolumn{2}{|c|}{$\begin{array}{l}\text { Mioma Uteri } \\
\quad(n=53)\end{array}$} & \multicolumn{2}{|c|}{$\begin{array}{l}\text { Tidak Mioma Uteri } \\
\qquad(\mathrm{n}=\mathbf{5 3})\end{array}$} & \multirow{2}{*}{ Nilai $p$} & \multirow{2}{*}{$\begin{array}{c}\text { OR } \\
(95 \% C I)\end{array}$} \\
\hline & $\mathrm{n}$ & $\%$ & $\mathrm{n}$ & $\%$ & & \\
\hline IMT $\geq 25$ & 5 & 9,4 & 11 & 20,8 & 0,104 & 0,398 \\
\hline IMT $<25$ & 48 & 90.6 & 42 & 79,2 & & \\
\hline
\end{tabular}

Dari tabel 6 di bawah menunjukkan bahwa dari 53 orang responden yang menderita mioma uteri, hampir seluruh $(77,4 \%)$ menggunakan $\mathrm{Kb}$ hormonal dan sebagian kecilnya $(22,6 \%)$ tidak menggunakan $\mathrm{Kb}$ hormonal dan dari 53 orang responden yang tidak mengalami mioma uteri, Sebagian besar $(50,9 \%)$ menggunakan kb hormonal dan hampir sebagian $(49,1 \%)$ tidak menggunakan kb hormonal. Hasil penelitian ya- 
ng dilakukan ditemukan responden yang tidak menggunakan kb hormonal mengalami mioma uteri dan responden yang tidak menggunakan kb hormonal tetapi mengalami mioma uteri.

Hasil analisis chi-square $\left(X^{2}\right)$ didapat nilai $p=0,005<\alpha=0,05$, artinya ada hubungan antara Penggunaan Kb Hormonal de- ngan kejadian mioma uteri di rumah sakit Kota Bengkulu tahun 2012. Selain itu diperoleh nilai OR 3,290 artinya ibu yang menggunakan $\mathrm{Kb}$ hormonal mempunyai risiko/berpeluang mengalami mioma uteri 1,47 kali dibanding ibu yang tidak menggunakan kb hormonal.

Tabel 6. Hubungan Kb-hormonal dengan Kejadian Mioma Uteri Kota Bengkulu Tahun 2012

\begin{tabular}{|c|c|c|c|c|c|c|}
\hline \multirow[t]{2}{*}{ Kb Hormonal } & \multicolumn{2}{|c|}{$\begin{array}{l}\text { Mioma Uteri } \\
\quad(n=53)\end{array}$} & \multicolumn{2}{|c|}{$\begin{array}{c}\text { Tidak Mioma Uteri } \\
(n=53)\end{array}$} & \multirow[t]{2}{*}{ Nilai $p$} & \multirow{2}{*}{$\begin{array}{c}\text { OR } \\
(95 \% C I)\end{array}$} \\
\hline & $\mathrm{n}$ & $\%$ & $\mathrm{n}$ & $\%$ & & \\
\hline $\mathrm{Ya}$ & 41 & 77,4 & 27 & 50,9 & 0.005 & 3,290 \\
\hline Tidak & 12 & 22,6 & 26 & 49,1 & & \\
\hline
\end{tabular}

\section{PEMBAHASAN}

\section{Hubungan Usia Ibu dengan Kejadian Mio-} ma Uteri

Hasil penelitian yang dilakukan menunjukkan bahwa dari 53 responden yang mengalami mioma uteri, hampir seluruh $(75,5 \%)$ responden berusia $\geq 35$ tahun, Sedangkan dari 53 responden yang tidak mengalami mioma uteri, hampir sebagian responden $(41,5 \%)$ berusia $\geq 35$ tahun. Hasil penelitian menunjukkan bahwa terdapat hubungan yang bermakna antara usia ibu dengan kejadian mioma uteri di rumah sakit kota Bengkulu tahun 2012. Ibu yang berusia $\geq 35$ tahun mempunyai resiko mengalami mioma uteri 4,336 kali dibanding ibu dengan usia $<35$ tahun.

Hasil penelitian yang dilakukan ditemukan responden yang berusia $<35$ tahun mengalami mioma uteri dan responden yang berusia $\geq 35$ tahun tetapi tidak menderita mioma uteri. Hal ini dapat dipengaruhi oleh faktor lain seperti $\mathrm{kb}$ hormonal dan paritas. Hasil penelitian sejalan dengan penelitian yang dilakukan Emirlia (2010) bahwa mioma uteri terjadi pada kelompok usia 36-45 tahun $(56,5 \%)$

Usia 20-30 tahun adalah usia reproduktif sehat yang tepat untuk mempunyai anak. Karena hormon estrogen diekresikan oleh ovarium mulai saat pubertas dan berangsur-angsur meningkat pada usia reproduktif. Penderita mioma pada usia 20-
35 tahun belum menimbulkan keluhan sehingga tidak terdeteksi. Insiden kejadian mioma uteri pada usia reproduktif sebesar 20\% (Cuningham, 2005)

Usia $\geq 35$ tahun pada wanita merupakan masa dimana seorang wanita telah mengalami penurunan fungsi berbagai organ dan sistim tubuh. Semakin tua usia seseorang semakin besar risiko terserang penyakit tertentu, salah satu yang berhubungan dengan organ reproduksi adalah mioma uteri, Hal ini merupakan degenerasi terhadap penambahan usia. Mioma uteri paling sering memberikan gejala klinis pada usia 35-45 tahun hal ini karena puncak dari stimulasi hormon estrogen dan progesteron. Insiden kejadian mioma uteri pada usia ini ditemukan 40-50\% (Suhatno, 2007).

\section{Hubungan Paritas dengan Kejadian Mioma Uteri}

Hasil penelitian yang dilakukan menunjukkan bahwa dari 53 yang menderita mioma uteri, sebagian kecilnya $(24,5 \%)$ adalah nulipara. Sedangkan dari 53 responden yang tidak mengalami mioma uteri, sebagian kecil $(20,8 \%)$ adalah nulipara. Hasil ini menunjukkan bahwa tidak ada hubungan antara paritas dengan kejadian mioma uteri di rumah sakit kota Bengkulu tahun 2012. Responden nulipara mempunyai risiko 0,817 kali menderita mioma uteri dibanding responden yang multipara 
Wiknjosastro (2007), bahwa Faktor risiko mioma uteri menunjukkan terdapat hubungan timbal balik antara paritas dengan terjadinya resiko mioma uteri, dimana wanita nulipara mempunyai resiko lebih tinggi mendapatkan mioma uteri dari pada wanita multipara. Hal ini disebabkan karena pada kehamilan akan mengurangi resiko paparan dengan estrogen. Sedangkan pada nulipara lebih lama mengalami paparan dengan estrogen

Hasil dari penelitian yang dilakukan ditemukan responden yang nulipara yang tidak mengalami mioma uteri dan responden multipara yang mengalami mioma uteri ini dapat dipengaruhi factor lain seperti usia dan kb hormonal. Menurut Manuaba, (2005), Peningkatan paritas menurunkan insiden terjadinya mioma uteri karena besarnya jumlah reseptor estrogen yang berkurang dilapisan miometrium setelah kehamilan. Beberapa penelitian menunjukkan terdapat hubungan timbal balik antara paritas dan kejadian mioma uteri. Pembuluh darah pada uterus kembali pada keadaan atau ukuran asal pada post partum. Dan ini menyebabkan mioma uteri kekurangan sulai darah dan kekurangan nutrisi untuk terus membesar. Kehamilan ketika usia Midreproductive (25-29 tahun) memberi perlindungan terhadap pembesaran mioma uteri (Parker, 2007)

Hasil penelitian ini didapati bahwa paritas tidak mempunyai hubungan dengan kejadian mioma uteri. Hasil penelitian ini tidak sesuai dengan beberapa teori dan pendapat diatas. Ketidaksesuaian ini kemungkinan disebabkan rata-rata pasien ginekologi yang datang ke rumah sakit secara umum adalah multi para dan. Namun hal ini sesuai dengan hasil penelitian Wacidah (2011), yang menyebutkan bahwa tidak terdapat hubungan antara paritas dengan kejadian mioma uteri.

\section{Hubungan Usia Menarche dengan Kejadian Mioma Uteri}

Hasil penelitian yang dilakukan menunjukkan bahwa dari 53 responden yang mengalami mioma uteri hampir sebagian $(30,2 \%)$ dengan usia menarche $<10$ tahun. Sedangkan dari 53 responden yang tidak menderita mioma uteri, hampir sebagian $(34 \%)$ dengan usia menarche $<10$ tahun.

Hasil penelitian menunjukkan tidak terdapat hubungan usia menarche dengan kejadian mioma uteri di rumah sakit kota Bengkulu tahun 2012. Responden dengan usia menarche $<10$ tahun memiliki risiko 0,835 kali dibanding dengan reponden dengan usia menarche $\geq 10$ tahun.

Hasil dari penelitian yang dilakukan ditemukan juga responden dengan usia menarche $\geq 10$ mengalami mioma uteri dan responden dengan usia menarche $<10$ tetapi tidak menderita mioma uteri. Hal ini dapat dipengaruhi faktor lain, seperti usia danpengunaan $\mathrm{kb}$ hormonal. Usia seorang wanita mengalami menarche bervariasi yaitu antara usia 10-16 tahun, tetapi ratarata pada usia 12,5 tahun. Mioma uteri dihubungkan dengan wanita yang mengalami menarche lebih awal, pada usia menarche $<10$ tahun mempunyai resiko lebih tinggi mendapatkan mioma uteri dari pada wanita dengan usia menarche 16 tahun. Hal ini diduga bahwa wanita dengan siklus menstruasi lebih awal akan meningkatkan jumlah pembelahan sel miometrium selama usia reproduksi, sehingga meningkatkan mutasi genetik yang mengontrol proliferasi mioma uteri (Wiknjosastro, 2005). Hasil penelitian tidak sesuai dengan teori yang dikemukakan diatas. Ketidaksesuaian ini kemungkinan disebabkan oleh karena masih terbatasnya jumlah sampel yang digunakan.sehingga distribusi sampelnya dinominasi oleh responden yang mengalami menarche pada usia $\geq 10$ tahun.

\section{Hubungan Obesitas dengan Kejadian Mio- ma Uteri}

Hasil penelitian yang dilakukan menunjukkan bahwa dari 53 responden yang mengalami mioma uteri, sebagian kecil $(9,4 \%)$ dengan nilai IMT $\geq 25 /$ obesitas, Sedangkan dari 53 responden yang tidak 
mengalami mioma uteri, sebagian kecil $(20,8 \%)$ dengan nilai IMT $\geq 25 /$ mengalami obesitas. Hasil penelitian menunjukkan bahwa tidak terdapat hubungan antara obesitas dengan kejadian mioma uteri dirumah sakit kota Bengkulu tahun 2012. Responden dengan nilai IMT $\geq 25 /$ Obesitas mempunyai risiko 0.174 kali mengalami mioma uteri dibanding responden dengan nilai IMT $<25$.

Obesitas secara umum dapat dikatakan kegemukan sebagai dampak dari konsumsi energi berlebihan, dimana energi yang berlebihan tersebut disimpan dalam tubuh sebagai lemak, sehingga akibatnya dari waktu ke waktu badan akan bertambah berat, disamping itu faktor kelebihan konsumsi energi, faktor keturunan juga memiliki andil dalam kegemukan (Muchtadi, 2001). Dari segi klinis obesitas adalah kelebihan lemak dalam tubuh, yang umumnya ditimbun dalam jaringan subkutan (bawah kulit), sekitar organ tubuh dan kadang terjadi perluasan kejaringan organnya. Menurut Bray, seseorang dikatakan obesitas bila $25 \%$ berat badan laki-laki terdapat lemak dan pada wanita lemak tubuhnya berjumlah $30 \%$ (FKUI, 2006).

Obesitas juga meningkatkan resiko terjadinya mioma uteri hal ini ada hubunganya dengan faktor hormonal yang mempengaruhi terjadinya obesitas, yang dapat menyebabkan peningkatan konversi adrogen andrenal kepada astron dan penurunan hormon sex-binding globulin. Hasilnya menyebabkan peningkatan estrogen secara biologikal yang bisa menerangkan mengapa terjadi peningkatan prevalensi mioma uteri dan pertumbuhanya (Parker, 2007). Penelitian yang dilakukan oleh Kurniasari (2009) ada hubungan signifikan antara IMT dengan kejadian mioma uteri, dengan IMT $>25$ didapat $(31,58 \%)$.

\section{Hubungan Kb-Hormonal dengan Kejadian Mioma Uteri}

Hasil penelitian yang dilakukan menunjukkan bahwa dari 53 responden.yang mengalami mioma uteri, hampir seluruh
$(77,4 \%)$ menggunakan kontrasepsi hormonal, Dan dari 53 responden yang tidak mengalami mioma uteri, sebagian besar $(50,9 \%)$ responden menggunakan kb hormonal. Hasil penelitian menunjukkan terdapat hubungan antara penggunaan kb hormonal dengan kejadian mioma uteri di rumah sakit Kota Bengkulu tahun 2012. Responden yang menggunakan kb hormonal mempunyai risiko mengalami mioma uteri 3.290 kali dibanding responden yang tidak menggunakan kb hormonal.

Hasil penelitian yang dilakukan ditemukan responden yang tidak menggunakan $\mathrm{kb}$ hormonal mengalami kejadian mioma uteri dan responden yang menggunakan $\mathrm{kb}$ hormonal tetapi tidak mengalami mioma uteri. Hal ini dapat dipengaruhi faktor lain, seperti usia dan paritas. Hormon yang mempengaruhi pertumbuhan dan perkembangan myoma adalah hormon estrogen dan progesteron. Menurut Parker (2007) yang mengutip pendapat Jhon and Martin (1971) melaporkan bahwa penggunaan oral kontrasepsi mempunyai peran pada pertumbuhan mioma. Sedangkan berdasarkan pendapat Ross (1986) menyatakan bahwa efek dari oral kontrasepsi terhadap mioma tergantung dari komposisi estrogen dan jenis progesterone dari kontrasepsi oral itu sendiri dimana pada penggunaan preparat progesteron ethidodral di asetat dilaporkan terjadi kenaikan insiden mioma uteri.

Perubahan fibroid sangat tergantung pada estrogen dan progesteron. Hormon estrogen dan progesteron pada wanita diperlukan untuk fibroid untuk tumbuh, tapi pertumbuhan fibroid memerlukan interaksi yang komplek antara estrogen, progesteron, dan faktor pertumbuhan sel (Parker, 2007). Hal ini diyakini bahwa estrogen dan progesteron memiliki mitogenik yang berpengaruh pada sel leiomioma dan juga bertindak dengan mempengaruhi baik secara langsung sejumlah besar factor pertumbuhan serta hormon lainya.

Penelitian yang dilakukan oleh Jian etal (2010) diperoleh hasil wanita yang menggunakan kontrasepsi oral memiliki 
risiko menderita mioma uteri 1.60 kali dibandingkan dengan wanita yang tidak. Hasil Penelitian ini sesuai dengan teori dan pendapat diatas serta Studi kasus pada penderita ginekologi yang dilakukan oleh Qonita, dkk (2011), dari 29 penderita mioma uteri didapatkan pengguna kontrasepsi hormonal (41,3\%), IUD (6,5\%), MOW $(6,5 \%)$ dan tidak ber kb sebanyak $(23,9 \%)$.

Marsall (2010), yang menjelaskan bahwa pertumbuhan dan perkembangan mioma uteri dipengaruhi oleh hormon estrogen. Terjadinya pemaparan estrogen dan progesteron dapat disebabkan oleh penggunaan kontrasepsi hormonal yang mengandung kombinasi hormon yaitu hormon estrogen dan progesteron. Hal ini sejalan dengan pendapat (Harianto, 2010) bahwa Di Indonesia Pemakai kontrasepsi hormonal terbanyak adalah jenis suntikan dan pil.

\section{KESIMPULAN}

Sebagian besar responden berusia $\geq 35$ tahun, sebagian kecil responden adalah Nullipara, hampir sebagian responden mengalami menarche pada usia $<10$ tahun, sebagian kecil responden mengalami obesitas, sebagian besar responden menggunakan kontrasepsi hormonal dan sebagian responden menderita mioma uteri. Ada hubungan antara usia ibu dengan kejadian mioma uteri di rumah sakit Kota Bengkulu tahun 2012. Tidak ada hubungan antara paritas dengan kejadian mioma uteri di rumah sakit Kota Bengkulu tahun 2012. Tidak ada hubungan antara usia menarche dengan kejadian mioma uteri di rumah sakit Kota Bengkulu tahun 2012. Tidak ada hubungan antara obesitas dengan kejadian mioma uteri di rumah sakit kota Bengkulu tahun 2012. Ada hubungan antara Penggunaan $\mathrm{Kb}$ hormonal dengan kejadian mioma uteri di rumah sakit kota Bengkulu tahun 2012.

Saran bagi Peneliti selanjutnya : hendaknya penelitian ini dapat dikembangkan pada penelitian lanjut yang mengungkapkan faktor-faktor lain yang dapat mempengaruhi kejadian mioma uteri dengan menggunakan jenis dan rancangan pene- litian berbeda. Bagi praktisi kesehatan : petugas kesehatan hendaknya mampu melakukan penapisan terhadap calon penggunaan kontrasepsi hormonal maupun pengguna kontrasepsi hormonal lanjutan/ ulangan dan mampu memberikan konseling yang baik. Sehingga akseptor dapat memilih kontrsepsi yang sesuai dengan kondisi tubuhnya. Petugas kesehatan hendaknya memberikan penyuluhan mengenai faKtor resiko, terutama pada kelompok yang berisiko yaitu wanita pada usia reproduktif. Selain itu tindakan pengawasan pemberian hormone estrogen dan progesterone dengan memilih pil $\mathrm{kb}$ kombinasi (mengandung hormone estrogen dan progesteron). Pil kombinasi mengandung estrogen lebih rendah dibanding pil sekuensil, oleh karena pertumbuhan mioma berhubungan dengan kadar estrogen. Petugas kesehatan hendaknya juga melakukan rehabilitasi untuk memulihkan seseorang yang sakit sehingga menjadi manusia yang produktif. Terutama kepada penderita mioma uteri pasca perawatan. Upaya rehabilitasi tidak hanya ditujukan pada rehabilitasi medic saja, tetapi juga menyangkut rehabilitasi jiwa. Penderita mioma uteri perlu mendapat dukungan moral, seorang penderita mioma uteri pasca histerektomi total (pengangkatan seluruh rahim) terlebih belum mempunyai anak dapat merasa kehilangan harga dirinya sebagai seorang wanita. Oleh sebab itu dukungan dari orang orang terdekat sangat diperlukan. Bagi wanita usia subur : hendaknya waspada terhadap resiko terjadinya mioma uteri. Dengan melakukan pemeriksaan lebih lanjut terhadap gejala kelainan siklus menstruasi. Bagi institusi pendidikan : seiring dengan perkembangan ilmu pengetahuan tentang hubungan usia dan mioma uteri maka hasil penelitian ini dapat dijadikan pendukung teori yang sudah ada. Bagi institusi pelayanan : hasil penelitian yang sudah ada diharapkan dijadikan sebagai bahan masukkan, pertimbangan dan informasi agar upaya peningkatan kesehatan reproduksi lebih ditingkatkan. 


\section{DAFTAR KEPUSTAKAAN}

Benson, Ralph dkk., 2008. Buku Saku Obsteteri dan Ginekologi. Edisi 9. Cetakan I. Jakarta: Penerbit EGC.

Cuningham, 2005, Obstetri Williams Edisi 21, Jakarta, EGC

Harianto, 2010, Dasar-dasar Obstetri dan Ginekologi, Jakarta

Mansjoer, 2007, Kapita Selekta Kedokteran edisi III Jilid I. Media Aesculapius. FKUI. Jakarta.

Manuaba, 2005, Kapita Selekta Penatalaksanaan Rutin Obstetri Ginekologi dan KB, EGC, Jakarta
Notoatmodjo, 2005, Ilmu Kesehatan Masyarakat, Rineka Cipta, Jakarta Kesehatan, Rineka Cipta, Jakarta

Nugroho, E., 2001. Esensial Obstetri dan Ginekologi. Edisi II. Penerbit Hipokrates, Jakarta.

Suhatno, 2007. Tumor Jinak pada Alat-alat Genitaldalam Buku Ilmu Kandungan. Yayasan Bina Pustaka Sarwono Prawirodihardjo, Jakarta

Wiknjosastro, 2005, Ilmu Kandungan, Yayasan Bina Pustaka Sarwono Prawirohardjo, Jakarta 